\title{
Peningkatan Kesadaran PHBS Pada Masyarakat Melalui Program Pemberdayaan Masyarakat di Dusun Ngandong Yogyakarta
}

\author{
Prabaswara Ulung Linuwih*, Naomi Nabila Pramayanti, Intan Kusumaningtyas \\ Program Studi S1 Kedokteran, Universitas Islam Indonesia \\ *Corresponding Email: ulunglinuwih6@gmail.com
}

\begin{abstract}
ABSTRAK
Kasus Hipertensi kini banyak ditemukan diseluruh lapisan masyarakat, bahkan hingga ke daerah pelosok. Tingginya prevalensi kasus tersebut sangat berkaitan dengan Perilaku Hidup Bersih dan Sehat (PHBS) masyarakat itu sendiri. Salah satu poin PHBS yang masih banyak diacuhkan adalah merokok. Banyak kalangan masyarakat masih mengkonsumsi rokok yang dapat menyebabkan hipertensi. Poin PHBS kedua yang kerap diacuhkan adalah konsumsi buah dan sayur. Realitanya, banyak masyarakat kurang mengontrol nutrisi yang dikonsumsi dalam sehari menyebabkan peningkatan kadar tertentu dalam tubuh. Hal tersebut tentunya memicu timbulnya penyakit seperti kolesterol tinggi, asam urat, bahkan diabetes. Kurangnya kesadaran ibu untuk melakukan poin PHBS terkait menimbang balita setiap bulan menyebabkan ketidaktauan seorang ibu terhadap status gizi anaknya dan menyebabkan kasus gizi kurang susah terdeteksi sejak dini. Program posyandu sangat brmanfaat untuk membantu monitoring dari status gizi anak. Upaya penurunan angka kasus tersebut dapat dilakukan dengan cara pencegahan. Tindakan preventif yang bisa dilakukan adalah dengan pemberian edukasi ke masyarakat. Pemebrian edukasi terkait PHBS bisa menjadi langkah preventif sekaligus promotif. Kasus lain yang biasanya timbul di masyarakat rural adalah gizi kurang. Tujuan kegiatan ini adalah untuk membantu dusun tersebut dengan pemberian alat kesehatan yang bisa digunakan untuk memonitoring kesehatan warganya yang dilakukan oleh kader desa yang terlatih, pemberian buku panduan terkait gizi seimbang serta memberikan edukasi kesehatan kepada warga melalui media poster. Kegiatan ini dilakukan satu kali dalam sebulan dimulai dari bulan September hingga Desember 2020.
\end{abstract}

Kata Kunci: Hipertensi, Gizi Seimbang, Edukasi, Masyarakat

\section{ABSTRACT}

Hypertension cases are now found in many levels of society, even in rural areas. The high prevalence of these cases is closely related to the Perilaku Hidup Bersih dan Sehat (PHBS) of the community itself. One of the PHBS points that many people ignore is smoking. Many people still consume cigarettes which can cause hypertension. The second PHBS point that is often overlooked is the consumption of fruits and vegetables. uncontrolled nutrient consumption in a day leads to increasing certain levels in the body. This condition can cause the incidence of diseases such as high cholesterol, uric acid, and even diabetes. The mother's lack of awareness of PHBS points related to weighing toddlers every month causes a mother didn't know about her child's nutritional status and malnutrition cases not detected early. The posyandu program is very useful to help monitor the nutritional status of children. Efforts to reduce the number of cases can be done with prevention action. Preventive action that can be taken is by presenting education to the public. Give the materials of education related to PHBS can be a preventive as well as a promotional step. Another case that usually occurs in rural communities is malnutrition. The purpose of this activity is to help the society by presenting medical devices that can be used to monitor the health of its residents by trained village cadres, presenting guidebooks related to nutrition also providing health 
education to residents using some posters This activity is carried out once a month starting from September to December 2020.

Keywords: Hypertension, Balnced Nutrition, Education, Society

\section{PENDAHULUAN}

Perilaku Hidup Bersih dan Sehat menjadi suatu langkah promotif yang dirancang oleh pemerintah untuk mengontrol kesehatan masyarakat. Pengertian dari PHBS sendiri adalah sekumpulan perilaku yang dipraktikan atas dasar kesadaran sebagai hasil pembelajaran yang menjadikan seseorang, keluarga, kelompok atau masyarakat mampu menolong dirinya sendiri di bidang kesehatan dan berperan aktif dalam mewujudkan kesehatan masyarakat (Kemenkes RI, 2011). Terdapat 10 poin PHBS, yaitu pertolongan persalinan oleh tenaga kesehatan, memberi bayi ASI ekslusif, menimbang balita setiap bulan, menggunakan air bersih, mencuci tangan dengan air bersih dan sabun, menggunakan jamban bersih dan sehat, memberantas jentik dirumah sekali seminggu, makan buah dan sayur setiap hari, melakukan aktivitas fisik setiap hari, dan tidak merokok di dalam rumah (Departemen Kesehatan RI, 2012). Poin PHBS tersebut sampai saat ini belum sepenuhnya diterapkan dalam masyarakat. Banyak masyarakat yang masih mengacuhkan dari poin-poin yang terdapat dalam PHBS.

Contoh kurangnya kesadaran masyarakat akan poin terakhir PHBS terkait dengan kebiasaan merokok adalah banyaknya kasus penyakit pernapasan dan hipertensi. Hipertensi merupakan kondisi dimana tekanan darah tubuh meningkat melebihi 120/80 mmHg (Agustina, 2019). Kondisi ini merupakan kontributor utama timbulnya penyakit yang berkaitan dengan sistem kardiovaskuler dan menjadi silent killer pada beberapa kondisi. Kasus hipertensi kebanyakan tidak terdeteksi sejak awal dan baru terdeteksi ketika sudah menimbulkan gejala, oleh sebab itu disebut sebagai silent killer (Kemenkes RI, 2019). Hipertensi kerap hadir dengan kondisi patologis lain, seperti adanya kadar kolesterol yang tinggi. Kadar koleterol yang tinggi apabila di biarkan saja akan mempengaruhi fungsi pembuluh darah yang pada akhirnya akan berakibat dengan peningkatan tekanan darah. Terdapat beberapa faktor resiko yang mempengaruhi tingkat kejadian hipertensi, yaitu jenis kelamin, usia, tempat tinggal, dan kerutinan melakukan pengukuran tekanan darah. Hipertensi lebih banyak terjadi pada wanita dibanding dengan pria dan biasanya lebih banyak diderita oleh orang yang sudah berumur. Selain itu, penduduk kota lebihkerap menderita hipertensi dikarenakan oleh sedentary lifestyle. Pada kasus hipertensi, kerutinan melakukan pengkuran tekanan memiliki presentase yang sangat sedikit dibanding dengan yang tidak melakukan pemeriksaan kesehatan (Muthmainnah, 2017; Agustina, 2019). Di daerah pedesaan, akses informasi dan edukasi kesehatan lebih rendah dibanding daerah kota. Hal ini berpengaruh terhadap kesadaran masyarakat untuk melakukan pengecekan kesehatan untuk mengetahui kadar tekanan darah, kolesterol, asam urat, dan glukosa darah. Indikator tersebut merupakan indikator umum dan sederhana yang bisa dilakukan di desa maupun dikota sebagai upaya promotif dan preventif yang bisa dilakukan untuk pengendalian penyakit penyakit yang berkaitan (Kemenkes RI, 2019).

Poin ketiga PHBS, yaitu menimbang balita tiap bulan juga menjadi perhatian khusus. Penimbangan balita setiap bulan merupakan salah satu unsur dalam pemantauan pertumbuhan. Program Pos Pelayanan Terpadu (Posyandu) adalah suatu kegiatan yang menitik beratkan pada upaya peningkatan dan pencegahan keadaan gizi anak (Budi, 2012). Peningkatan berat badan pada anak merupakan suatu indikator penting yang mencerminkan pertumbuhan anak. Dari pemeriksaan ini, ibu juga dapat mengetahui status gizi anak dan menjadi suatu metode skrining apakah anak memiliki resiko gizi kurang atau keterlambatan pertumbuhan perkembangan (Riawati, D., Hanifah, 2017). Tingkat partisipasi ibu untuk mengikuti kegiatan posyandu dipengaruhi oleh beberapa faktor sepeti umur ibu, pekerjaan, tingkat pendidikan suami dan istri, dukungan keluarga, jarak dari rumah ke posyandu serta kehadiran tenaga kesehatan. Mayoritas, ibu yang datang ke posyandu merupakan ibu yang masih termasuk dalam usia reproduktif, selain itu, ibu dengan tingkat pendidikan yang 
tinggi juga kebanyakan lebih sadar terkait pentingnya memonitoring tumbuh kembang anak sehingga memahami urgensi diadakanya posyandu (Budi, 2012).

\section{METODE}

Pengabdian Masyarakat ini dilakukan di Dusun Ngandong, Girikerto, Turi, Sleman, Yogyakarta. Kegiatan ini dilaksanakan satu kali setiap bulan dan dimulai pada tanggal 25 September 2020 sampai dengan bulan Desember 2020. Kegiatan pengabdian masyarakat dilakukan dengan metode pemberian sarana berupa alat kesehatan dan metode Komunikasi Informasi Edukasi (KIE). Pemberian sarana alat kesehatan diharapkan dapat membantu kader terlatih untuk melakukan monitoring dan skrining penyakit yang kerap timbul di masyarakat. Dalam mengoptimalkan sarana dan prasarana yang ada, diberikan pula buku panduan yang berisi cara -cara penggunaan alat kesehatan serta pedoman gizi seimbang. Metode Komunikasi Informasi Edukasi dilaksanakan menggunakan media poster yang diperoleh dari website resmi pemerintah dan dilakukan penyuluhan setelah pemasangan poster. Poster yang diberikan meliputi 4 tema, yaitu cara penggunaan masker yang benar, langkah cuci tangan, informasi umum COVID-19 dan himbauan untuk petani pada kondisi pandemi.

\section{PELAKSANAAN DAN PEMBAHASAN}

Kedokteran - LEM FK UII, melalui departemen Pengabdian Masyarakat (PENGMAS) kembali mengadakan kegiatan bakti sosial bersifat kotinyu Desa Binaan (DESBIN) 2020. Kegiatan DESBIN ini diadakan oleh beberapa anggota Pengmas dan dibantu oleh mahasiswa aktif FK UII lainnya. Kegiatan tersebut dilakukan di Dusun Ngandong, Kecamatan Turi, Kabupaten Sleman pada 26 September 2020.

Kegiatan DESBIN ini merupakan kegiatan yang dilaksanakan tiap bulan, dan berlangsung pada bulan September hingga bulan Desember 2020 dalam bentuk sosialisasi yang ditunjukan kepada 6 kader terlatih dan pemberian bantuan logistik berupa alat-alat pemeriksaan ke dusun Ngandong. Kegiatan ini dilakukan betujuan untuk upaya meningkatkan status kesehatan masyarakat dusun Ngandong yang terbilang masih rendah.

Kegiatan Desbin dibuka dengan memberikan batuan logistik untuk menunjang pemeriksaan yang dilakukan oleh kader-kader terlatih di Balai Dusun Ngandong, Turi, Sleman, D.I Yogyakarta. selain pemeriksaan, panitia Desbin juga melakukan pembekalan kepada kader terkait protocol kesehatan yang harus diperhatikan dalam pemeriksaan yang akan datang. Kemudian dilanjutan dengan penyuluhan edukasi terkait hal-hal apa saja yang harus dilakukan dan dihindari saat pandemik COVID-19 pada 26 September pada pukul 10.00 WIB sampai dengan 11.00 WIB.

Pada tanggal 25 Oktober pada pukul 10.00 WIB dilakukan pemasangan poster edukatif oleh panitia DESBIN. Pemasangan tersebut juga dilanjutkan dengan presentasi atau penyuluhan kepada masyarakat dusun Ngandong. Selain pemasangan poster, panitia DESBIN juga melakukan pemantuan terhadap pemeriksaan Balita yang dilakukan oleh kader. Pemeriksaan meliputi tinggi badan, berat badan dan pemantuan tehadap buku KIA. Alhamdulillah, seluruh rangakaian kegiatan DESBIN pertemuan pertama dan kedua berjalan dengan lancar. 


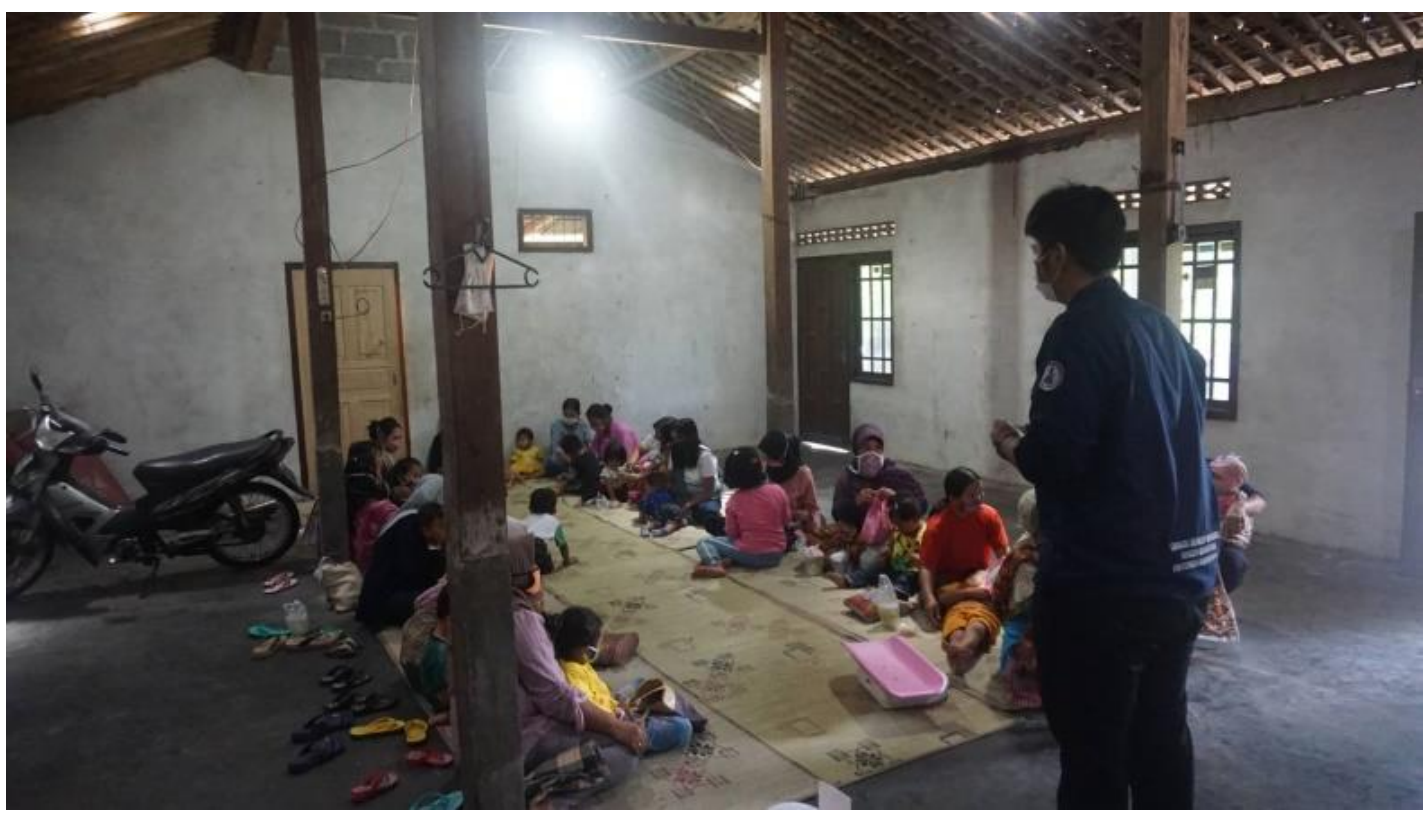

(Gambar 1. Penyuluhan tentang Pandemi Covid-19)

\section{SIMPULAN}

Kegiatan DESBIN dapat memberikan dampak positif dalam membantu meningkatkan status kesehatan masyarakat dusun Ngandong melalui bantuan pemeberian alat alat pemeriksaan. Pengetahuan masyarakat akan bahaya COVID-19 dan penyakit-panyakit lain juga meningkat seiring dengan dilakukannya penyuluhan serta penempelan media poster. Hal ini dibuktikan dengan kuisioner yang diisi oleh kader-kader menunjukan skor yang lebih baik dari batas minimal yang sudah ditentukan sebelumnya.

\section{UCAPAN TERIMA KASIH}

Penulisan ini dapat terwujud dan terselesaikan dengan baik karena adanya bantuan dari berbagai macam pihak: Pertama, Kepala dusun Ngandong. Kedua, pihak penyelenggara Dana Hibah desa 2020. Ketiga, pihak terkait yang telah membantu dalam kelancaran pelaksanaan acara. Dalam penyusunan ini, pihak penulis menyadari masih banyak kekurangan karena keterbatasan pengatahuan. Oleh karena itu, segala kritik dan saran yang bersifat membangun sangat diharapkan. Semoga penulisan ini dapat membrikan manfaat dan dapat menjadi salah satu bahan informasi pengetahuan bagi para pembaca sekalian

\section{DAFTAR PUSTAKA}

Agustina, V. (2019). Kejadian Penyakit Hipertensi Dan Indeks Massa Tubuh Pada Perempuan Yang Tinggal Di Pedesaan Dan Perkotaan. Jurnal Kesehatan Kusuma Husada, 127-136.

Budi, A. (2012). Faktor-Faktor Yang Berhubungan Dengan Partisipasi Ibu Untuk Menimbang Balita ke Posyandu, Jurnal Kedokteran Yarsi, 20(3), 143-157.

Departemen Kesehatan RI. (2012). Rumah Tangga Sehat Dengan Perilaku Hidup Bersih dan Sehat, Pusat Promosi kesehatan.

Kemenkes RI. (2011). Pedoman pembinaan Perilaku Hidup Bersih dan Sehat, Kementrian Kesehatan Republik Indonesia.

Kemenkes RI. (2019). Hipertensi Si Pembunuh Senyap, Kementrian Kesehatan RI, 1-5. https://pusdatin.kemkes.go.id/resources/download/pusdatin/infodatin/infodatin-hipertensi-sipembunuh-senyap.pdf.

Muthmainnah, S. (2017). Hubungan Dukungan Keluarga dengan Kepatuhan Minum Obat pada Pasien Hipertensi di Rumah Sakit Umum Kecamatan Cempaka Putih Tahun 2017, 1-9.

Riawati, D., \& Hanifah, L. (2017). Evaluasi Pertumbuhan Balita Berdasarkan Umur dan Berat Badan. Jurnal Kebidanan Indonesia, 8(2), 85-96. 